\title{
Online hotel ratings and its influence on hotel room rates: the case of Lisbon, Portugal
}

\author{
Online hotel ratings e a sua influência nos preços dos hotéis: o caso de Lisboa, Portugal
}

\author{
Conceição Castro \\ Polytechnic Institute of Porto, Porto Accounting and Business School, CEOS.PP, CEPESE, Rua Jaime Lopes Amorim, 4465-004 S. \\ Mamede de Infesta, Portugal, mariacastro@iscap.ipp.pt
}

Fernanda A. Ferreira

Polytechnic Institute of Porto, School of Hospitality and Tourism, CITH/P.Porto, Applied Management Research Unit (UNIAG), Rua D. Sancho I, 981, 4480-876 Vila do Conde, Portugal, faf@esht.ipp.pt

\begin{abstract}
Lisbon is one of the European Union cities that has one of the highest growth in the number of hotels. With the digital revolution, travelers can easily not only compare prices but also get information about the experience of other guests which can influence prices. The aim of this paper is to analyze how prices for a hotel stay can be influenced by some quality signaling factors, as star rating and online consumer's ratings (location, cleanliness, comfort, facilities, staff and value for money, available on Booking.com), the volume of consumer's comments and the availability of rooms in Lisbon. For 151 hotels in Lisbon, from 3 to 5 stars, through a multiple regression model, the results suggest that hotel category, location and facilities ratings have a positive influence on hotel room rates, but higher trade-off between what clients pay and the guest hotel stay experience has a negative impact on the consumer's willingness to pay, as well as the number of comments. Among different hotel categories, the influent factors are different. Our main findings provide signs to hoteliers to take corrective actions towards the attributes most valuable for consumers and that can provide a higher room rate premium.
\end{abstract}

Keywords: Online hotel ratings, hedonic prices, Lisbon hotels, Booking.com.

\section{Resumo}

Lisboa é uma das cidades da União Europeia onde o número de hotéis tem tido uma das maiores taxas de crescimento. Com a revolução digital os turistas podem facilmente comparar preços bem como obter informações acerca da experiência dos hóspedes, o que pode influenciar os preços. $\mathrm{O}$ objetivo deste artigo é o de analisar de que forma os preços podem ser influenciados por fatores sinalizadores de qualidade, como a categoria (número de estrelas), avaliações online (localização, limpeza, conforto, comodidades, funcionários e relação qualidade/preço, disponíveis no booking.com), o número de comentários dos hóspedes e a disponibilidade de quartos em Lisboa. Para 151 hotéis, de 3 a 5 estrelas, através de um modelo de regressão múltipla, os resultados sugerem que a categoria do hotel, os ratings de localização e comodidades têm uma influência positiva no preço, mas um maior trade-off entre o que os clientes pagam e a experiência que usufruem tem um impacto negativo na vontade de pagar, assim como o número de comentários. Verifica-se, ainda, que os fatores influentes diferem entre hotéis com diferentes categorias. Os resultados fornecem pistas para os hoteleiros promoverem ações corretivas relativamente aos atributos mais valorizados e que podem proporcionar um maior prémio no preço dos quartos.

Palavras-chave: Online hotel ratings, preços hedónicos, hotéis de Lisboa, Booking.com.

\section{Introduction}

In recent years we have witnessed a global expansion of the hotel industry and an increased mobility of international travelers, and Lisbon, the capital of Portugal, was one of the European cities that experienced a greater increase in international arrivals. Lisbon is an ideal place for tourism, since it gathers a variety of characteristics in a relatively small area, which is especially useful to cover a larger number of visitors with different types of objectives and budgets (Castro, Ferreira $\&$ Vasconcelos, 2015). From heritage monuments, historic districts as Alfama, Mouraria, Bairro Alto and Chiado, sports, beaches, natural parks, cafes and terraces, movida, gastronomy, luxury hotels and the Fado, recognized as intangible world heritage by UNESCO, the city has provoked the attention of more visitants as well as investors.

Nowadays hotels have the difficult assignment of provide quality for clients that are more quality conscious but also practice reasonable prices at a time that travelers have greater price-sensibility (Smith \& Spencer, 2011). Most hoteliers claim that highly satisfied guests are much more likely to return to the property and spend more time during future stays than guests

who are indifferent or displeased. As Taleb Rifai, SecretaryGeneral of the World Tourism Organization, said "Tourism is about experiences" (UNWTO, 2014, p. 1) and with the proliferation of the use of smartphones, tablets and other mobile internet devices, travelers have more opportunities to share experiences and influence others.

The digital revolution has changed the way consumers book and research travel. According to UNWTO (2014, p. 6) “Before making an online hotel reservation, consumers visit on average almost 14 different travel-related sites with about three visits per site, and carry out nine travel-related searches on search engines". Besides that, travelers have the opportunity to share their points of view about their experiences, serving also as a recommendation (Zhang, Ye \& Law, 2011) and according to PhoCusWright, a global travel market research organization, $50 \%$ of global travelers do not book a room until they have read reviews online. Websites prominently display consumers' product ratings, which influence consumers' buying decisions and willingness to pay. Prior research has indicated that the impacts caused by online reviews influences the decision making process of hotel customers (Serra Cantallops \& Salvi, 2014). 
Online reviews provide useful information about customers' satisfaction. Some attributes such as the room facilities, the value for money, the location, the service and staff were identified as a key attributes from the internet reviews that underpin customer satisfaction (Chaves, Gomes \& Pedron, 2011; O'Connor, 2010; Zhou, Ye, Pearce \& Wu, 2014). Furthermore, recent research has revealed that the online reviews have impact on hotel business performance. Xie, Zhang \& Zhang (2014), for example, showed significant associations with hotel performance in focusing upon the effect of online reviews for certain hotel attributes (i.e., services, location, price, room, and cleanliness). More specifically, they found that ratings for purchase value are negatively associated with performance.

Phillips, Barnes, Zigan \& Schegg (2016) propose a model that helps to explain which aspects of visitor experience, as voiced through social media, have the greatest impact on hotel demand (measured by percent Room Occupancy) and subsequently revenue (measured by RevPAR, a ratio that reflects the amount of revenue per available guest room).

Previous literature has studied the determinants of hotel room rates, which are determined by a set of characteristics and attributes of the hotel. The online ratings can be seen as the consumer's perceived quality for the service or attribute and are likely to influence hotel room rates.

The aim of this paper is to analyze how the quality of a variety of hotel attributes, measure by several consumer online ratings, star rating, and the availability of rooms influence room rates of hotels in Lisbon, as a whole and for different hotel categories. This paper is expected to make contributions to the current body of literature, since represents one of the first effort to investigate the determinants of hotel room prices in Lisbon based on quality signaling factors. The results of this study may also contribute to hoteliers to improve their strategy on prices based on guest satisfaction of a variety of attributes.

The article is organized as follows. Section 2. outlines the literature review; Section 3. outlines the research objectives, model and covering the data source; followed by Section 4 . which exhibits the analysis and results. Finally, Section 5 . summarizes the main conclusions and present the limitations of the current work, and also outlines directions for future research.

\section{Literature review}

Many studies on the determinants of hotel room rates have adopted the hedonic price model, in which the price of a good or service is the sum of unobserved or implicit prices (since they are not traded individually on the market) of the set of its attributes or characteristics. The idea behind this method is that the presence or absence of these attributes or characteristics influence the hotel quality and so the costumer's willingness to pay for the stay in the hotel. Empirically, the coefficients estimated from the hedonic price model for each characteristic provide information about the consumer willingness to pay in the presence of it and so how businesses can increase the price by including particular characteristics (Yang, Mueller \& Croes, 2016). Some empirical studies in tourism and hospitality have been conducted using the hedonic price model.

There are several hotel attributes, identified in literature, that may affect hotel room rates: reputational attributes, as star rating which is a quality signal creating a premium price (Abrate, Capriello \& Fraquelli, 2011; Abrate, Fraquelli \& Viglia, 2012; Andersson, 2010; Castro \& Ferreira, 2015; Castro et al., 2015; Espinet, Saez, Coenders \& Fluvià, 2003; Schamel, 2012; Thrane, 2007; Zhang, Zhang, Cheng \& Zhang, 2011) and consumers ratings (Andersson, 2010; Castro \& Ferreira, 2015; Castro et al., 2015; Herrmann \& Herrmann, 2014; Schamel, 2012); location attributes that determine the proximity to attractions for guests, as the distance to city centers or beaches (Espinet, Saez, Coenders, \& Fluvià, 2003; Herrmann \& Herrmann, 2014; Hung, Shang and Wang, 2010; Rigall-I-Torrent, Fluvià, Ballester, Ariza \& Espinet, 2011; Schamel, 2012); facilities of the hotel: swimming pool (Chen \& Rothschild, 2010; Espinet et al., 2003; Thrane, 2007), fitness centre or sport facilities (Andersson, 2010; Chen \& Rothschild, 2010; Espinet et al., 2003), business or conference centre (Chen \& Rothschild, 2010; Schamel, 2012), restaurant (Thrane, 2007), bar (Chen \& Rothschild, 2010; Schamel, 2012), garden or terrace (Espinet et al., 2003), internet access (Chen \& Rothschild, 2010; Schamel, 2012), shuttle (Chen \& Rothschild, 2010), parking place (Espinet et al., 2003; Thrane, 2007); facilities and amenities in the room: minibar (Abrate et al., 2011; Schamel, 2012), air conditioning (Abrate et al., 2011), room service (Schamel, 2012; Thrane, 2007); among others. The number of available rooms is also important to the definition of pricing policies (Badinelli, 2000; Gallego \& Ryzin, 1994; White \& Mulligan, 2002), as the prices tend to increase with the scarcity of hotels available to book (Abrate et al., 2012).

With the advance in technology, travelers changed their behaviour, namely the purchasing process, due to the availability of information. A study by Google/IPSOS OTX 2011, indicates that more and more people are sharing their own experiences in the internet in order to guide prospective customers and $45 \%$ make personal travel plans and $54 \%$ make business travel plans based on the online reviews. In fact, nowadays, travelers spend some time searching online information when they are planning a trip. Consumers may choose one hotel due to the price, location, services provided, the quality of the services and other attributes of the hotel. The services provided by a hotel include not only the lodging services but also a set of supplementary services and attributes that increase the experience of the customers. Although room rates can be easily compared, the purchase of a hotel stay still has a high level of uncertainty because consumers cannot judge the quality of these attributes and facilities before buying it. This can be reduced by gathering more information about the hotel before buying it, trying to compare what they can know about the experience of other guests with the price they must 
pay (Zhang, Ye \& Law, 2011). Online reviews and ratings have an important role in the decision-making process, reducing uncertainty. The positive and negative evaluations posted by other customers help travelers to make their choice, and the digital revolution has boosted this process. When a potential client reads a positive (negative) review it increases (decreases) his booking intention (Park \& Lee, 2008; Tsao, Hsieh, Shih \& Lin, 2015). They act as quality signals reducing "the information asymmetries in the market by offering buyers information on the quality of products they intend to purchase" (Yang et al., 2016, p. 42).

Some authors claim that it is not only the customer rating level or online reviews that influence customer's choice and hotels performance, but also the quantity of discuss about the attribute (Cheung \& Thadani, 2012; Blal \& Sturman, 2014). Large number of reviews can make those reviews seem more trustworthy (Zhu \& Zang, 2010; Xie et al., 2014) and reinforce the idea that customers should book a hotel stay that was booked by many others (Xie et al., 2014). According to Molinillo, Ximénez-de-Sandoval, Fernández-Morales \& Coca-Stefaniak (2016), the hotel's credibility can be higher when the number of customer reviews posted online increases, although it can be related to the size of the hotel. Using the ratio number of reviews per number of rooms, they conclude that this ratio decline as the hotel size increases and has a positive relationship with a hotel's overall customer rating. Another important conclusion of this article is that as the size of hotels increases the number of high scores decreases.

Although most of the literature focus on the impact of online reviews or ratings on the making-decision process, there are some studies that analyze the influence of these quality signaling factors as an attribute influencing hotel room rates (Abrate et al., 2011; Andersson, 2010; Öğüt \& Taş, 2012; Yang et al., 2016; Zhang, Ye \& Law, 2011).

Zhang, Ye \& Law (2011), using a hedonic price model, studied the variations of hotel room rates in New York city through the influence of the star rating, number of reviews and guest ratings for the quality of the room, location, cleanliness and service disposable on Tripadviser. For the whole sample star rating, room quality and location are significant predictors of room prices. Neverheless theses atributes differ between lodging segments. While in economy hotels the quality of the rooms is statisticaly significant in explainning the variance in the room rates, in midlescale segments, besides the quality of the room, the convenient location is also important, and for luxury hotels are location and the quality of the services. On the contrary Borges, Pereira, Matos \& Borchardt (2015), using panel data for hotels in 25 different countries, on the period from July to September 2013, concluded that guest ratings from Booking.com for location, confort, cleanliness, services, staff and value for money, plus room avaliability and number of evaluations from guest aren't predictors of customers' willingness to pay for a stay in those hotels.
Anderson (2012) using data from three different sources shows that a $1 \%$ improvement in reviews score translates into a $1 \%$ gain in RevPAR and theses gains are higher for midle class hotels than for luxury hotels in seven cities in the USA. Besides that, this study also indicates that the probably of a consumer book a hotel increases 1.142 if their Travelocity Review Score increases by one point. In consequence, a one-point gain on online reputation creates an $11 \%$ gain in price (when the hotel chooses to increase prices) and still mantains its occupancy rate.

\section{Research design, model and data}

In Lisbon, hotels with 3, 4 and 5 stars accommodated $74 \%$ of total guests in 2014, and they represent $68 \%$ of the lodging capacity (hotels, apartment hotels, Pousadas, tourist villages, tourist apartments and others), while more than half is on hotels with 4 and 5 stars (INE, 2016a, 2016b). The net room occupancy rate of bedrooms in hotel establishments was $60.2 \%$ in 2014, the highest of Portuguese NUTS II regions, preceded by the Autonomous Region of the Madeira (Eurostat, 2016).

For the purpose of this study we selected one of the most important online hotel booking platforms with global reach: Booking.com. The reviews in this online travel agency may be written only by a customer who has actually stayed in the reviewed hotel booked through the Booking.com website. These reviews and ratings should be considered as more objective, and subject to less manipulation compared with others. Booking.com is the world leader in booking accommodations online and provides attribute evaluations for all the hotels, although the number of customers that rate each hotel is different (see Exhibit 1).

Exhibit 1 - Example of guest ratings from Booking.com

$100 \%$ Verified Reviews Real guests. Real stays. Real opinions

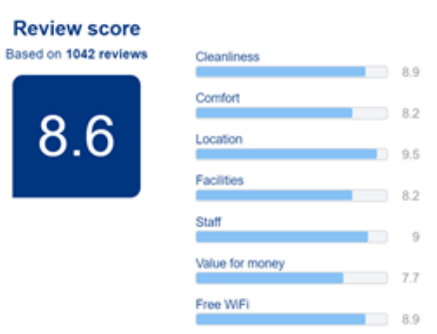

Source: Booking.com.

As suggested in prior literature we selected the guest ratings and star rating as quality signals, the number of comments and room availability to examine if they influence and how the willingness to pay a stay in a hotel.

In order to attain our research objective, we conducted a quantitative study and analyzed the 151 hotels with three to five stars in Lisbon, according to the Nomenclature of Territorial Units for Statistics (NUTs II) using the following methodology: we gathered the names of all hotels in the Lisbon region registered up to March 31, 2016 in the website 
www.booking.com, and using this website, we collected the room rate for a one night stay in a standard double room with breakfast included and free cancellation (the booking was made four months in advance), the customers reviews scores about Cleanliness, Location, Staff, Comfort, Facilities and Value for money, the Number of comments from each hotel and the number of available rooms in the moment of booking. It wasn't including the consumer rating Free Wifi due to the fact that Wifi is also considered in Facilities.

The data analysis prosecuted, using SPSS, consisted on the following methods. First, some descriptive statistics were calculated to describe the basic features of the data studied, namely the main measures of central tendency and dispersion. A cluster analysis was performed in order to aggregate the variables in homogeneous groups. The dendrogram was draw, displaying the rescaled distance cluster combine. Lastly, the Ordinary Least Square (OLS) regression analysis was applied to a hedonic price model to find which variables could explain differences in the hotel room rates in Lisbon as a whole and for hotels with different star ratings. Court (1939, in Goodman, 1998) and Rosen (1974), advises semilog (or log-linear) specification for the pricing function instead of the linear specification. This is mainly because semilog specification gives "more nearly linear and higher sample correlations" (Court, 1939, p. 110 in Goodman, 1998).

It is assumed that the functional relationship is constant in time and cross hotels, although the influence of each attribute may differ from hotel to hotel (Espinet et al., 2003). The hedonic price model is:

$$
\operatorname{Ln}(\text { Room rate })=\beta_{0}+\beta_{1 i} \sum_{i=1}^{n} X_{i}+\beta_{2 j} \sum_{j=1}^{p} Y_{j}+\varepsilon,
$$

where $X_{i}$ is the vector of quality signals and includes: guest ratings - the hotel online guest ratings, which captures the electronic word of mouth gathered from the travel review website, Booking.com (on a scale from 1.0 to 10.0) which are disaggregated in the following scores: Staff, Location, Facilities, Comfort, Cleanliness and Value for money; and star rating - an official indicator of the hotel quality, which ranges from one to five. Since we only had three different hotel's category (three, four and five star hotels), it was created two dummy variables (5_Star and 4_Star) defined as: 5_Star= "1" if the hotel has a five-star rating, "0" otherwise; 4_Star= "1" if the hotel has a four-star rating, " 0 " otherwise. $Y_{j}$ is a vector of other variables selected from the literature review: room availability - the number of rooms available on the moment of booking; and number of comments - the number of reviews online posted by guest on the website Booking.com.

\section{Results and discussion}

\subsection{Statistics Descriptive statistics and multivariate analysis}

Table 1 presents the descriptive statistics of the variables used in the empirical analysis.

Table 1 - Definition and descriptive statistics of variables $(n=151)$

\begin{tabular}{|l|c|c|c|c|c|c|}
\hline \multicolumn{1}{|c|}{ Variable } & Mean & Median & Standard Deviation & Coefficient of variation & Mínimum & Maximum \\
\hline Room rate & 141.97 & 121.63 & 60.90 & 0.43 & 58.00 & 380.00 \\
\hline Room availability & 6.75 & 7.00 & 3.19 & 0.08 & 1 & 10 \\
\hline Cleanliness & 8.68 & 8.70 & 0.69 & 0.08 & 6.50 & 9.80 \\
\hline Comfort & 8.32 & 8.40 & 0.80 & 0.10 & 5.80 & 9.70 \\
\hline Location & 8.61 & 8.50 & 0.75 & 0.09 & 6.90 & 9.90 \\
\hline Facilities & 8.12 & 8.20 & 0.75 & 0.06 & 5.80 & 9.50 \\
\hline Staff & 8.63 & 8.70 & 0.63 & 0.07 & 6.90 & 9.80 \\
\hline Value for money & 8.03 & 8.10 & 0.50 & 0.07 & 6.50 & 9.00 \\
\hline Number of comments & $1,450.65$ & $1,133.50$ & $1,222.68$ & 0.84 & 73 & 7,768 \\
\hline
\end{tabular}

There were 151 hotels, $15.9 \%$ of which have 5 stars, $54.3 \%$ with 4 stars and $29.8 \%$ with 3 stars. For the total sample, the medium price was $€ 141.97$ with a standard deviation of $€ 60.90$. The minimum price was $€ 58.00$ and the maximum $€ 380.00$. Its observable a lag between the minimum (73) and the maximum $(7,768)$ in the number of comments from clients. The ratings for the indexes of satisfaction are all higher than 8.03 (in a scale of 1-10) which reflect favourable experiences during the hotel stay, and the coefficients of variation for the mean are low. The higher coefficient of variation on the consumer's ratings is 0.10 and concerns to the variable Comfort. Among all the variables, the higher coefficient of variation is 0.84 and concerns to the variable Number of comments.

The results of the bivariate Pearson correlation coefficients among the various Booking.com ratings of hotels, the Room availability, Number of comments, and Room rates are presented in Table 2. 
Table 2 - Correlation matrix

\begin{tabular}{|c|c|c|c|c|c|c|c|c|c|c|c|}
\hline & 1. & 2. & 3. & 4. & 5. & 6. & 7. & 8. & 9. & 10. & 11. \\
\hline 1. $\operatorname{Ln}($ Room rate $)$ & 1 & & & & & & & & & & \\
\hline 2. $\operatorname{Ln}(N$. of comments) & $-0.416^{* * *}$ & 1 & & & & & & & & & \\
\hline 3. Location & $0.583^{* * *}$ & $-0.133^{*}$ & 1 & & & & & & & & \\
\hline 4. Facilities & $0.661^{* * *}$ & $-0.145^{* *}$ & $0.485^{* * *}$ & 1 & & & & & & & \\
\hline 5. Value for money & $0.371^{* * *}$ & -0.006 & $0.437^{* * *}$ & $0.857^{* * *}$ & 1 & & & & & & \\
\hline 6. Staff & $0.671^{* * *}$ & $-0.318^{* * *}$ & $0.658^{* * *}$ & 0.873 & 0.775 & 1 & & & & & \\
\hline 7. Cleanliness & $0.623^{* * *}$ & $-0.172^{* *}$ & $0.555^{* * *}$ & $0.959 * * *$ & $0.885^{* * *}$ & $0.901^{* * *}$ & 1 & & & & \\
\hline 8. Comfort & $0.652^{* * *}$ & $-0.149 * *$ & $0.441^{* * *}$ & $0.976 * * *$ & $0.835^{* * *}$ & $0.827 * * *$ & $0.939 * * *$ & 1 & & & \\
\hline 9. Room availability & -0.01 & $0.196 * * *$ & $-0.149 * *$ & 0.033 & -0.023 & $-0.132 *$ & 0.009 & 0.05 & 1 & & \\
\hline 10. 5_Stars & $0.515^{* * *}$ & $-0.165^{* *}$ & 0.094 & $0.293 * * *$ & $0.130 *$ & $0.234 * * *$ & $0.211 * * *$ & $0.309 * * *$ & 0.034 & 1 & \\
\hline 11.4_Stars & 0.045 & -0.078 & -0.055 & $0.199 * * *$ & 0.084 & $0.108^{*}$ & 0.188 & $0.233^{* * *}$ & 0.072 & $-0.462 * * *$ & 1 \\
\hline
\end{tabular}

Source: Research data (2016).

According to the results, Facilities are strong and positively correlated with Value for money, Staff, Cleanliness and Comfort; Value for money with Cleanliness, and Comfort; Staff with Cleanliness and Comfort; Cleanliness with Comfort. It is also observable the correlation between hotel room rates and Staff, Facilities, Comfort, Cleanliness, Location, 5-star rating, Ln of the Number of comments and Value for money, all statistically significant at $1 \%$.

The very high correlations among the partial ratings are suggestive that hotel guests might have the tendency to generalize and experience 'halo effect' - if they evaluate the hotel highly on one of the attributes they might be more generous on the others as well. The reverse might be also true - if they evaluate the hotel very low on one of the ratings, customers might tend to depress their score for the other ratings as well.

\subsection{Cluster analysis}

The goal of this cluster analysis is to identify homogeneous groups of variables. We will look to the variables, indicators of the customer level of satisfaction after their stay in destinations, considering the whole sample and analyze the average scores for these variables: Cleanliness, Comfort, Location, Service, Staff and Value for money. We also consider the variables Room availability and the Ln (Number of comments). We apply a hierarchical cluster analysis based on Euclidean distances, using the single linkage method. Before we start with the clustering process, we have to examine the variables for substantial collinearity. There are several variables that have high correlations, as we saw in Table 2. We should reduce variables, for example, by omitting Cleanliness and Comfort. The remaining few variables still provide a sound basis for carrying out cluster analysis.

The hierarchical method was used for the selection of the final cluster solution to group variables. Using the Euclidean distance that is suitable for only continuous variables, for measuring similarity or distance, we obtain the results reported in Table 3. The smallest difference is between Facilities and Value for Money (5.07) and the largest distance (47.46) occurs between Location and Room availability (Table 3 ).

Table 3 - Proximity matrix

\begin{tabular}{|c|c|c|c|c|c|c|}
\hline & Location & Facilities & Staff & Value for money & Room availability & Ln(Number of comments) \\
\hline Location & 0 & & & & & \\
\hline Facilities & 11.095 & 0 & & & & \\
\hline Staff & 7.133 & 7.716 & 0 & & & \\
\hline Value for money & 11.094 & 5.069 & 8.785 & 0 & & \\
\hline Room availability & 47.463 & 43.347 & 47.020 & 42.849 & 0 & \\
\hline Ln(Number of comments) & 24.865 & 20.288 & 25.060 & 17.698 & 38.631 & 0 \\
\hline
\end{tabular}

Source: Research data (2016).

Using the Ward's hierarchical procedure, because equally sized clusters are expected and no outliers are present, and examining the dendrogram we have a four-cluster solution for the online review ratings, and for each cluster, the means for all variables were calculated. Then, for each case, the squared Euclidean distance to the cluster means is calculated. As it can be seen in the dendrogram that Location and Staff ratings were classified into the same cluster (cluster 1 ) by the hierarchical procedure, while the second cluster (cluster 2 ) associates Value for money and Facilities ratings. Room availability and Ln (Number of comments) were set apart (of the cluster analysis) of the previous ratings, and considered as the third and fourth clusters (Figure 1).
Figure 1 - Dendrogram using Ward Linkage

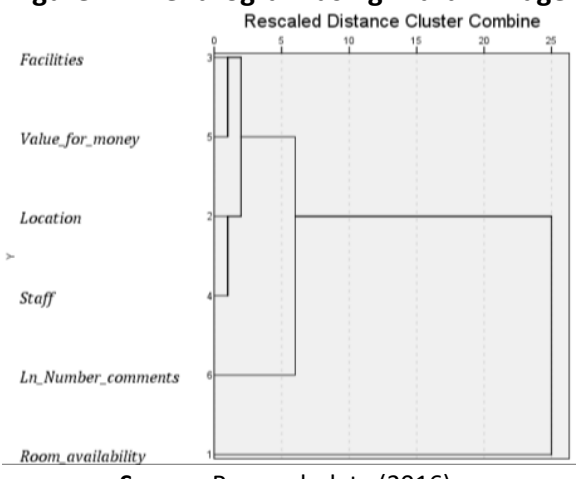

Source: Research data (2016). 


\subsection{Regression analysis}

4.3.1 Room rates determinants for the overall hotels with 3 to 5 stars

$\operatorname{Ln}\left(\right.$ Room rate $\left._{i}\right)=\beta_{0}+\beta_{1}$ Cleanliness $_{i}+\beta_{2}$ Comfort $_{i}+\beta_{3}$ Location $_{i}+\beta_{4}$ Facilities $_{i}+\beta_{5}$ Staf $_{i} f+\beta_{6}$ Value for money $_{i}+$

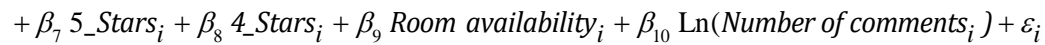

$i=1,2, \ldots, n$.

Dependent variable: Logarithm of hotel room rates (Table 4).

Table 4 - Measuring the impact of travels satisfaction on hotel room rates

\begin{tabular}{|c|c|c|c|c|}
\hline \multirow[b]{2}{*}{ Variables } & \multicolumn{2}{|c|}{ Model 1} & \multicolumn{2}{|c|}{ Model 2} \\
\hline & Coefficient & VIF & Coefficient & VIF \\
\hline \multirow[t]{2}{*}{ Constant } & $3.705^{* * *}$ & & $3.696 * * *$ & \\
\hline & $(11.944)$ & & $(13.657)$ & \\
\hline \multirow[t]{2}{*}{ Ln(Number of Comments) } & $-0.088 * * *$ & 1.418 & $-0.083 * * *$ & 1.107 \\
\hline & $(-4.448)$ & & $(-4.941)$ & \\
\hline \multirow[t]{2}{*}{ Location } & $0.186^{* * *}$ & 2.098 & $0.181^{* * *}$ & 1.125 \\
\hline & $(7.136)$ & & $(8.4 .81)$ & \\
\hline \multirow[t]{2}{*}{ Facilities } & $0.308^{* * *}$ & 37.047 & $0.363^{* * *}$ & 6.653 \\
\hline & $(2.776)$ & & (7.799) & \\
\hline \multirow[t]{2}{*}{ Value for money } & $-0.354 * * *$ & 6.115 & $-0.352 * * *$ & 4.846 \\
\hline & $(-5.320)$ & & $(-5.995)$ & \\
\hline \multirow[t]{2}{*}{ Staff } & -0.014 & 9.459 & & \\
\hline & $(-0.214)$ & & & \\
\hline \multirow[t]{2}{*}{ Cleanliness } & 0.014 & 22.539 & & \\
\hline & $(0.154)$ & & & \\
\hline \multirow[t]{2}{*}{ Comfort } & 0.050 & 26.767 & & \\
\hline & $(0.573)$ & & & \\
\hline \multirow[t]{2}{*}{ Room availability } & 0.003 & 1.170 & & \\
\hline & $(0.732)$ & & & \\
\hline \multirow[t]{2}{*}{ 5_Stars } & $0.321^{* * *}$ & 2.247 & $0.331^{* * *}$ & 2.025 \\
\hline & $(5.698)$ & & $(6.258)$ & \\
\hline \multirow[t]{2}{*}{ 4_Stars } & 0.060 & 2.091 & $0.069 *$ & 1.907 \\
\hline & $(1,525)$ & & (1.859) & \\
\hline Adjusted R-square & 0.784 & & 0.788 & \\
\hline $\mathrm{F}$ test & $55.319 * * * *$ & & $93.810 * * * *$ & \\
\hline DW & 1.949 & & 1.941 & \\
\hline Number of observations & 151 & & 151 & \\
\hline
\end{tabular}

The first model (Model 1) includes all tested variables. On this model some of the variables of quality signals - Staff, Cleanliness and Comfort are not statistically significant. Although Facilities is significant, the high variance inflation factor (VIF) denotes high collinearity, as does Cleanlinesss and Comfort ratings and this warns that they can't be all included in the same model. This high collinearity may result from the fact that guests usually tend to evaluate the different attributes on the same way: positively if they had a positive experience or
In the next step we run the regression based on the hedonic price model (eq. [1]) that can be expressed as follows: 
The model 2, as measured by the adjusted R-squared, shows that $78.8 \%$ of the variance in $\operatorname{Ln}($ Room rates) are explained by the variables included in the analysis. The F-ratio is significant at the 0.01 level. This provides evidence of the existence of a linear relationship between the $\operatorname{Ln}$ (Room rates) and the explanatory variables. All VIF are below the cut-off point of 10, so multicollinearity does not seem to be a problem in our model. The t-statistic test was used for testing whether the independent variables contribute to the predicator of the dependent variable.

The online quality signaling factors - Facilities and Location - are significant and positive. An incremental point in the Facilities score is associated with hotels price premium of $43.8 \%$. Our results also suggest that the higher is the evaluation of guest satisfaction with the Location the higher are the room rates on Booking.com. "The notion has been that the typical tourist wants to be within walking distance of tourist attractions" (Arbel \& Pizam, 1977, p. 18). In Lisbon, the centre is a fairly compact area, and the average and median distance of the hotels to the centre - Rossio Square - are $2.5 \mathrm{~km}$ and $2 \mathrm{~km}$, respectively, with a standard deviation of $2 \mathrm{~km}$. Although Lisbon is equipped with a good public transport, comprising both underground and surface, and the distance to the hotels to public transports (bus and metro) is not far ( $0.5 \mathrm{~km}$ in average), the proximity to access points for public transport should also be considered. Regarding all these aspects and according to our results it seems that consumers are willing to pay more $19.8 \%$ for a stay when there is one incremental point in the Location score.

On the contrary Value for money rating has a negative and significant impact on room rates. Value for money, in tourism, is a concept that "captures both price and quality in one construct" (Smith \& Spencer, 2011, p. 96) and measures the trade-off between the price paid and the hotel stay experience. Supposing imperfect information, the negative impact of Value for money may reflect that expectations of customers were higher and haven't been fulfilled considering the price charged, or the price was too high for the services offered. This result is consistent with Xie et al. (2014) and Borges et al. (2015) although in this work Value for money is not statistically significant.

The star rating dummies are significant and the transformed estimated coefficients evaluate the average price premium that consumers are willing to pay with respect to a three-star hotel. Accordingly, predicted room rates for hotels with four stars are 7.1\% higher than those with three stars, and, similarly, five star hotels charge $39.2 \%$ higher room rates than those with three stars, ceteris paribus. We can see the increase in predict room rates as the number of stars increases, mainly in hotels of five stars.

The results also suggest that the number of online customer reviews per hotel room has a direct but negative impact in room rates.

\subsubsection{Room rates determinants for each category of hotels}

The results for the overall hotels in Lisbon with 3, 4 and 5 stars suggested that only some quality signaling factors have an impact on prices. Since customers have different expectations and usually they are higher when prices are higher (Zhang, Ye and Law, 2011; Blal \& Sturman, 2014), next we examine if the willingness to pay a stay in a hotel with different category (star rating) is determined by different quality attributes, the volume of customers online reviews and room availability.

Table 5 reports the descriptive statistics for the three segments, according to the star rating. As was expected hotels with 5 stars practice the highest prices but also have the highest coefficient of variation. The consumer ratings for each attribute, in average, decrease as the category of the hotel decreases, which indicates that consumer ratings reflect the hotel service quality (Riegner, 2007). Guests of 5 and 4 star hotels give the highest scores for Cleanliness and Staff, in average, and for 3 star hotels the highest scores are for Location followed by Staff. For these attributes the rating for Comfort are most dispersive in 3 star hotels and Location in 4 and 5 star hotels. 3 star hotels have a larger volume of consumer reviews in average.

Table 5 - Descriptive statistics for samples of hotels by star rating

\begin{tabular}{|c|c|c|c|c|c|c|c|c|c|c|c|c|c|c|c|}
\hline \multirow{2}{*}{ Variable } & \multicolumn{5}{|c|}{5 star hotels } & \multicolumn{5}{|c|}{4 star hotels } & \multicolumn{5}{|c|}{3 star hotels } \\
\hline & Mean & Median & SD & Min & Max & Mean & Median & SD & Min & Max & Mean & Median & SD & Min & Max \\
\hline Room rate & 209.84 & 203.94 & 65.39 & 109.00 & 380.00 & 138.56 & 123.19 & 42.23 & 79.00 & 239.00 & 104.70 & 98.00 & 28.45 & 58.00 & 201.25 \\
\hline $\begin{array}{l}\text { Room } \\
\text { availability }\end{array}$ & 7.13 & 7.50 & 2.89 & 1.00 & 10.00 & 6.95 & 7.50 & 3.14 & 1.00 & 10.00 & 6.16 & 6.00 & 3.45 & 1.00 & 10.00 \\
\hline Cleanliness & 9.04 & 9.00 & 0.53 & 7.60 & 9.70 & 8.80 & 8.75 & 0.53 & 7.50 & 9.80 & 8.27 & 8.40 & 0.84 & 6.50 & 9.70 \\
\hline Comfort & 8.90 & 8.85 & 0.50 & 7.70 & 9.70 & 8.48 & 8.50 & 0.56 & 7.10 & 9.60 & 7.68 & 7.80 & 0.91 & 5.80 & 9.30 \\
\hline Location & 8.79 & 8.60 & 0.66 & 7.40 & 9.80 & 8.57 & 8.50 & 0.78 & 6.90 & 9.80 & 8.57 & 8.50 & 0.74 & 7.00 & 9.90 \\
\hline Facilities & 8.64 & 8.45 & 0.54 & 7.30 & 9.50 & 8.25 & 8.20 & 0.55 & 6.80 & 9.30 & 7.58 & 7.80 & 0.84 & 5.80 & 9.10 \\
\hline Staff & 8.98 & 9.05 & 0.53 & 7.40 & 9.70 & 8.69 & 8.70 & 0.56 & 7.20 & 9.80 & 8.32 & 8.40 & 0.68 & 6.90 & 9.60 \\
\hline $\begin{array}{l}\text { Value for } \\
\text { money }\end{array}$ & 8.19 & 8.20 & 0.42 & 7.40 & 9.00 & 8.07 & 8.10 & 0.41 & 7.20 & 9.00 & 7.87 & 8.00 & 0.64 & 6.50 & 9.00 \\
\hline $\begin{array}{l}\text { Number of } \\
\text { comments }\end{array}$ & $1,071.6$ & 663.5 & 996.1 & 199.0 & $3,592.0$ & $1,450.9$ & $1,089.0$ & $1,370.3$ & 73.0 & $7,768.0$ & $1,679.2$ & $1,368.0$ & 995.1 & 395.0 & $4,284.0$ \\
\hline
\end{tabular}


The results for each category (Table 6) show differences in the determinants of room rates.

Table 6 - Regression coefficients for 5, 4 and 3 star hotels

\begin{tabular}{|c|c|c|c|c|c|c|}
\hline & 5 star hotels & & 4 star hotels & & 3 star hotels & \\
\hline & Coefficient & VIF & Coefficient & VIF & Coefficient & VIF \\
\hline \multirow[t]{2}{*}{ Constant } & $3.990 * * *$ & & $4.185^{* * *}$ & & $2.184 * * *$ & \\
\hline & (4.776) & & $(12,673)$ & & (7.857) & \\
\hline \multirow[t]{2}{*}{ Value of money } & $-0.584 * * *$ & 2.502 & $-0.373 * * *$ & 3.149 & & \\
\hline & $(-3.672)$ & & $(-5.563)$ & & & \\
\hline \multirow[t]{2}{*}{ Cleanliness } & $0.674 * * *$ & 2.502 & & & & \\
\hline & (5.2326) & & & & & \\
\hline \multirow[t]{2}{*}{ Location } & & & $0.199 * * *$ & 1.498 & $0.203^{* * *}$ & 1.501 \\
\hline & & & (8.170) & & $(5.271)$ & \\
\hline \multirow[t]{2}{*}{ Facilities } & & & $0.337 * * *$ & 3.936 & $0.092^{* * *}$ & 1.501 \\
\hline & & & (5.977) & & (2.716) & \\
\hline \multirow[t]{2}{*}{ Ln(Number of coments) } & & & $-0.111 * * *$ & 1.054 & & \\
\hline & & & $(-6.318)$ & & & \\
\hline Adjusted R-square & 0.579 & & 0.767 & & 0.632 & \\
\hline F test & $14.441 * * *$ & & $67.516 * * *$ & & $38.817^{* * *}$ & \\
\hline DW & 2.491 & & 1.896 & & $1,836.000$ & \\
\hline Number of observations & 24 & & 82 & & 45 & \\
\hline
\end{tabular}

Notes: Student t-values in parentheses; ${ }^{* *}$ Statistically significant at $1 \% ;{ }^{* *}$ statistically significant at $5 \% ;{ }^{*}$ statistically significant at $10 \%$ Source: Research data (2016).

Cleanliness quality is the factor that has the higher impact on predictable prices in 5 star hotels, but only in this category of hotels. Considering that this type of hotels has higher quality of services and facilities, and, in Lisbon, are mostly located near the center (see Figure 2), it means that consumers are willing to pay more if the Cleanliness has higher ratings. Value for money is a quality attribute common to 5 and 4 stars and with a negative and significant impact on room rates, mainly in 5 star hotels. This can mean that customers had higher expectations than they get to the price they pay, or the price is too high, which has a negative impact on the consumer's willingness to pay for a stay.

In both 4 and 3 stars the guest ratings that potentially impact positively room rates are those related with Location and Facilities. An increase of one point on the Facilities score increases prices about $40 \%$ in 4 star hotels and $9.6 \%$ in 3 star hotels, while the impact of one point on the Location score increases price about $22 \%$ in either those two categories of hotels. This may result from the fact that hotels with 3 and 4 stars have a higher dispersion in physical location, as can be seen in Figure 2, and so, consumers are willing to pay more for a convenient location. The volume of online reviews only impacts negatively room rates on 4 star hotels.

Figure 2 - Biplot component loadings and objects

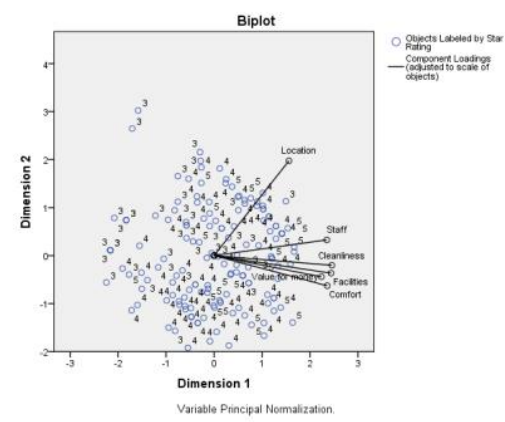

Source: Research data (2016).

\section{Conclusion, limitations and future research}

The increase of mobile devices for making hotel bookings enhances the importance of online reviews and ratings, which are the result of experiences of previous guests. Even if consumers don't book the hotel online, they take into account these reviews and scores in the hotel selection process. Online reviews and ratings are quality signals for travelers and if these signals are of high quality, consumers are willing to pay more for a stay in the hotel. Beyond the official star rating, that is consensually an important determinant of room rates, and also a quality signaling factor, the scores resulting from guest's opinions can be seen as quality attributes of the hotel and, according to the hedonic price model, determinants of room rates. Those reviews and scores can't be seen as a threat for the hoteliers, but rather can be used to improve the business performance and guest loyalty. In this sense, the present investigation on the determinants of room prices in Lisbon, based mainly on quality signal factors, may provide clues to hoteliers in identify and take corrective actions towards the attributes most valuable for consumers and that can provide a higher room rate premium.

The website Booking.com discloses, for each hotel, ratings for Staff, Cleanliness, Comfort, Facilities, Location and Value for money. Our cluster analysis suggests four clusters for these ratings, Number of comments and Room availability. Guests punctuate in a similar way Staff and Location, forming a cluster, Value for money and Facilities forming another homogeneous group. The other variables, Number of comments and Room availability compose two different clusters.

The results of the regression analyses suggest that the consumer's willingness to pay a stay in a hotel in Lisbon increases with the star rating, convenient location and facilities 
provided. The negative impact of the rating for value for money on room rates suggest the "low price may make good purchase value for money" (Xie et al., 2014, p. 8) while it may also reduce room prices. Nevertheless, the relevance of the quality signalling factors differs among hotels with different categories. In five star hotels, the quality of cleanliness and value for money are significant in explaining the variance in room prices. This suggest that hoteliers of this segment should invest in the cleanliness in order to enhance guest ratings. They also should improve what customers get from the experience regarding the price they pay. In four star hotels, besides the negative impact of value for money, there are two more quality signalling factors that may influence room prices, and that are common with three star hotels: facilities and location. So, on these segments, managers should focus on facilities in order to enhance guest ratings. In four star hotels the hoteliers should also improve the value of guest experience.

As any piece of research, this work presents some limitations. Other quality signaling factors as chain and quality certification could be included in our analysis.

In future research, besides the inclusion of the omitted quality factors, and also following Booking.com's rating system it could be analyzed the impact of attributes ratings on hotel room rates capturing different preferences among customer segments and between domestic and foreign costumer ratings.

\section{Acknowledgments}

UNIAG, R\&D unit funded by the FCT - Portuguese Foundation for the Development of Science and Technology, Ministry of Science, Technology and Higher Education, under the Project UID/GES/04752/2016.

\section{References}

Abrate, G., Capriello, A. \& Fraquelli, G. (2011). When quality signals talk: Evidence from the Turin hotel industry. Tourism Management, 32(4), 912-921.

Abrate, G., Fraquelli, G. \& Viglia, G. (2012). Dynamic pricing strategies: Evidence from European hotels. International Journal of Hospitality Management, 31, 160-168.

Anderson, C. K. (2012). The Impact of Social Media on Lodging Performance. Center for Hospitality Research Report, 12 (15).

Andersson, D.E. (2010). Hotel attributes and hedonic prices: an analysis of internet-based transactions in Singapore's market for hotel rooms. The Annals of Regional Science, 44, 229-240.

Arbel, A. \& Pizam, A. (1977) Some Determinants of Urban Hotel Location: The Tourists' Inclinations. Journal of Travel Research, 15(3): 18-22. Doi: 10.1177/004728757701500305

Badinelli, R. (2000). An optimal, dynamic policy for hotel yield management. European Journal of Operational Research, 121, 476-503.

Blal, I. \& Sturman, M. C. (2014). The differential effects of the quality and quantity of online reviews on hotel room sales. Cornell Hospitality Quarterly, 55(4), 365-375.

Borges, I., Pereira, G., Matos, C. \& Borchardt, M. (2015). Análise da relação entre a satisfação dos consumidores e os preços ofertados no sítio booking.com. Tourism \& Management Studies, 11(2), 64-70.

Castro, C. \& Ferreira, F. A. (2015). Effects of Hotel Characteristics on Room Rates in Porto: a Hedonic Price Approach, AIP Conference Proceedings 1648, 070002.
Castro, C., Ferreira, F. A. \& Vasconcelos, L. (2015). Effects of hotel characteristics on room rates in Lisbon: A hedonic price approach. In Vânia Costa (Ed.) Tourism for the $21^{\text {st }}$ Century. Proceeding of the CIT 2015 (pp. 1153-1165), Guimarães: Instituto Politécnico do Cávado e do Ave.

Chaves, M., Gomes, R. \& Pedron, C. (2011). Analysing reviews in the Web 2.0: Small and medium hotels in Portugal. Tourism Management, 33(5), 1286-1287.

Chen, C. \& Rothschild, R. (2010). An application of hedonic pricing analysis to the case of hotel rooms in Taipei. Tourism Economics, 16(3), 685-694.

Cheung, C. \& Thadani, D. (2012). The impact of electronic word-ofmouth communication: A literature analysis and integrative model. Decision Support Systems, 54 (1), 461-70.

Espinet, J. M., Saez, M., Coenders, G. \& Fluvià, M. (2003). Effects on Prices of the Attributes of Holiday Hotels: A Hedonic Prices Approach. Tourism Economics, vol. 9(2), 165-177.

Eurostat (2016). Net occupancy rate of bed-places and bedrooms in hotels and similar accommodation (NACE Rev. 2, I, 55.1) by NUTS 2 regions (from 2012 onwards) [Database]. Retrieved April 30, 2016, from http://appsso.eurostat.ec.europa.eu/nui/submitViewTableAction.do

INE (2016a). Guests (No.) in hotel establishments by Geographic localization (NUTS - 2013) and Type (hotel establishment); Annual [Statistical data]. Retrieved April, 30, 2016 from https://www.ine.pt/xportal/xmain?xpid=INE\&xpgid=ine_indicadores\& indOcorrCod $=0008577 \&$ contexto $=b d \&$ selTab $=$ tab2

INE (2016b). Lodging capacity (No.) in hotel establishments by Geographic localization (NUTS - 2013) and Type (hotel establishment; Annual [Statistical data]. Retrieved April, 30, 2016 from https://www.ine.pt/xportal/xmain?xpid=INE\&xpgid=ine_indicadores\& indOcorrCod $=0008574 \&$ contexto $=b d \&$ selTab=tab2

Gallego, G. \& Ryzin, G. (1994). Optimal dynamic pricing of inventories with stochastic demand over finite horizons. Management Science, 40, 999-1020.

Goodman, A. C. (1998). Andrew Court and the Invention of Hedonic Price Analysis. Journal of Urban Economics, 44, 291-298.

Google/IPSOS OTX. MediaTraveler's Road to Decision 2011. Retrieved May 5, 2016, from http://www.gstatic.com/ads/research/en/2011_TravelersRoadtoDecis ion2011.pdf.

Herrmann, R. \& Herrmann, O. (2014). Hotel room rates under the influence of a large event: The Oktoberfest in Munich 2012. International Journal of Hospitality Management, 39, 21-28.

Hung, W., Shang, J. \& Wang, F. (2010). Pricing determinants in the hotel industry: Quantile regression analysis. International Journal of Hospitality Management, 29, 378-384.

Molinillo, S., Ximénez-de-Sandoval, J., Fernández-Morales, A. \& CocaStefaniak, A. (2016). Hotel Assessment through Social Media: The case of TripAdvisor. Tourism \& Management Studies, 12(1), 15-24. Doi: 10.18089/tms.2016.12102

O'Connor, P. (2010). Managing a hotel's image on TripAdvisor. Journal of Hospitality Marketing \& Management, 19(7), 754-772.

Öğüt, H. \& Taş, B. (2012). The influence of internet customer reviews on the online sales and prices in hotel industry. The Service Industries Journal, 32 (2), 197-214.

Park, D. \& Lee, J. (2008). eWOM overload and its effect on consumer behavioral intention depending on consumer involvement. Electronic Commerce Research and Applications,7 (4), 386-398.

Phillips, P., Barnes, S., Zigan, K. \& Schegg, R. (2016). Understanding the Impact of Online Reviews on Hotel Performance: An Empirical Analysis. Journal of Travel Research. Doi: 10.1177/0047287516636481.

Riegner, C. (2007). Word of mouth on the web: the impact of Web 2.0 on consumer purchase decisions. Journal of Advertising Research, 47(4), 436-447. 
Rigall-I-Torrent, R., Fluvià, M., Ballester, R., Saló, A., Ariza, E. \& Espinet, J. M. (2011). The effects of beach characteristics and location with respect to hotel prices. Tourism Management, 32, 1150-1158.

Rosen, S. (1974). Hedonic Prices and Implicit Markets: Product Differentiation in Pure Competition. Journal of Political Economy, 82(1), 34-55.

Schamel, G. (2012).Weekend vs. midweek stays: Modelling hotel room rates in a small market. International Journal of Hospitality Management, 31 (4), 1113-1118.

Serra Cantallops, A. \& Salvi, F. (2014). New consumer behavior: A review of research on eWOM and hotels. International Journal of Hospitality Management, 36, 41-51.

Smith, T. \& Spencer, A. (2011). Predictors of Value for Money in Jamaican All-Inclusive Hotels. International Journal of Humanities and Social Science, 1(4), 93-102.

Thrane, C. (2007). Examining the determinants of room rates for hotels in capital cities: The Oslo experience. Journal of Revenue and Pricing Management, 5(4), 315-323.

Tsao, W-C., Hsieh, M-T., Shih, L-W. \& Lin, T. (2015). Compliance with eWOM: The influence of hotel reviews on booking intention from the perspective of consumer conformity. International Journal of Hospitality Management, 46, 99-111.

White, P. \& Mulligan, G. (2002). Hedonic Estimates of Lodging Rates in the Four Corners Region. The Professional Geographer, 54 (4), 533-543. World Tourism Organization (UNWTO) (2014). Online Guest Reviews and Hotel Classification Systems - An Integrated Approach. Madrid: UNWTO.

Xie, K., Zhang, Z. \& Zhang, Z. (2014). The business value of online consumer reviews and management response to hotel performance. International Journal of Hospitality Management, 43, 1-12.

Yang, Y., Mueller, N. \& Croes, R. (2016). Market accessibility and hotel prices in the Caribbean: The moderating effect of quality-signaling factors. Tourism Management, 56, 40-51.

Zhang, H., Zhang, J., Lu, S., Cheng, S. \& Zhang, J. (2011). Modeling hotel room price with geographically weighted regression. International Journal of Hospitality Management, 30, 1036-1043.

Zhang, Z., Ye, Q. \& Law, R. (2011). Determinants of hotel room price: An exploration of travelers' hierarchy of accommodation needs". International Journal of Contemporary Hospitality Management, 23(7), 972-981.

Zhou, L., Ye, S., Pearce, P.L. \& Wu, M.-Y. (2014). Refreshing hotel satisfaction studies by reconfiguring customer review data. International Journal of Hospitality Management, 38, 1-10.

Zhu, F. \& Zhang, X. (2010). Impact of online consumer reviews on sales: the moderating role of product and consumer characteristics. Journal of Market, 74(2), 133-148.

Received: 20 March 2017

Revisions required: 23 May 2017

Accepted: 20 July 2017 